\title{
Measurement of microbial biomass N:C by chloroform fumigation-incubation
}

\author{
D. Harris ${ }^{1}$, R. P. Voroney ${ }^{2}$, and E.A. Paul ${ }^{1}$ \\ ${ }^{1}$ Department of Crop and Soil Sciences, Michigan State University, East Lansing, Michigan 48824-1325, USA, \\ E-mail harrisd@pilot.msu.edu; and 2University of Guelph, Ontario, Canada N1G 2W1. Received 11 July 1996, \\ accepted 29 April 1997.
}

\begin{abstract}
Harris, D., Voroney, R. P. and Paul, E. A. 1997. Measurement of microbial biomass N:C by chloroform fumigation-incubation. Can. J. Soil Sci. 77: 507-514. We present a calculation for soil microbial biomass N:C ratio determined from a 10-d incubation following chloroform fumigation. The calculation is based on a mathematical model of the $\mathrm{N}$ content of the pre- and post-fumigation soil microbial biomass and the growth yield of the biomass that develops after fumigation. Biomass $\mathrm{N}$ is calculated from the $\mathrm{N}: \mathrm{C}$ ratio and biomass $\mathrm{C}$. The mineralization of bacteria and fungi, with different $\mathrm{N}$ contents, added to fumigated soils was used to establish the model parameters. The model was tested against an independent set of measurements and considers two assumptions: 1) The ratio of $\mathrm{N}$ : C mineralized from killed biomass is equal to the ratio of $\mathrm{N}: \mathrm{C}$ mineralized from soil nonbiomass constituents. 2) More realistically, the $\mathrm{N}$ and $\mathrm{C}$ mineralization in the fumigated soil, from sources other than killed biomass, is a residual fraction of the $\mathrm{N}$ and $\mathrm{C}$ mineralization in the unfumigated soil. Biomass $\mathrm{C}: \mathrm{N}$ ratios calculated without a control correction (assumption 1) were, on average, $20 \%$ wider than corrected values (assumption 2). Biomass $\mathrm{N}$ calculated as the product of $\mathrm{N}: \mathrm{C}$ and biomass $\mathrm{C}$ was compared with published values for several data sets. The new calculation method was robust even when net immobilization of $\mathrm{N}$ followed fumigation.
\end{abstract}

Key words: Soil microbial biomass, nitrogen, chloroform fumigation, C:N ratio

\begin{abstract}
Harris, D., Voroney, R. P. and Paul, E. A. 1997. Mesure du rapport N:C de la biomasse microbienne par fumigation au chloroforme et incubation. Can. J. Soil Sci. 77: 507-514. Nous présentons une formule de calcul de rapport N:C de la biomasse microbienne $(\mathrm{BM}) \mathrm{du}$ sol après fumigation au chloroforme suivie d'une période d'incubation de 10 jours. Les calculs sont basés sur un modèle mathématique de la teneur en $\mathrm{N}$ de la $\mathrm{BM}$ avant et après la fumigation et de l'accroissement de la BM observé après la fumigation. Le $\mathrm{N}$ de la $\mathrm{BM}$ est calculé à partir du rapport $\mathrm{N}: \mathrm{C}$ et du $\mathrm{C}$ de la biomasse. La minéralisation des bactéries et des champignons microscopiques, de teneurs azotées différentes, incorporés aux sols fumigés est utilisée pour établir les paramètres du modèle. Le modèle, testé sur un ensemble indépendant de mesures, examine deux hypothèses : 1) le rapport N:C minéralisé à partir de la biomasse tuée est égale à celui obtenu pour les composantes du sol autre que la biomasse et 2) de façon plus réaliste, la minéralisation de $\mathrm{N}$ et de $\mathrm{C}$ dans le sol fumigé, à partir de matières autres que la biomasse est une fraction résiduelle de celle mesurfée dans le sol fumigé. Les rapports $\mathrm{C}: \mathrm{N}$ de la biomasse microbienne calculés sans correction (hypothèse 1 temoins) étaient en moyenne $20 \%$ plus larges que les valeurs corrigées (hypothèse 2). Le $\mathrm{N}$ de biomasse microbienne calculé comme étant le produit de N:C et du C de la biomasse est comparé aux valeurs publiées pour plusieurs ensemble de données. Il appert que la nouvelle méthode de calcul est valable même lorsque la fumigation est suivie d'une immobilisation nette de l'azote.
\end{abstract}

Mots clés: Biomasse microbienne du sol, azote, fumigation, chloroforme, rapport C:N

The soil microbial biomass is both an agent of biochemical change and a significant pool of labile nutrients. It serves key roles in nutrient cycling and soil fertility in both agricultural and natural systems. Measurement of the content of $\mathrm{C}, \mathrm{N}$ and other nutrients in the microbial biomass is important to our understanding of these fundamental processes. When combined with isotopic tracers these measurements can also give estimates of transfer rates between functional pools.

The $\mathrm{N}$ content of the soil microbial biomass has been estimated from measurements of the $\mathrm{N}$ released following chloroform fumigation using one of two methods, fumigationincubation and fumigation-extraction. In fumigation-incubation, $\mathrm{N}$ mineralized to ammonium in a $10-\mathrm{d}$ incubation following chloroform fumigation is measured (Jenkinson and Powlson 1976; Shen et al. 1984). In fumigation-extraction (Brookes et al. 1985), the materials released by fumigation are immediately extracted in $\mathrm{K}_{2} \mathrm{SO}_{4}$ solution. Acid digestion converts the extracted $\mathrm{N}$ to ammonium which can be directly measured or further processed for mass spectrometry. Both methods have disadvantages and advantages. We have chosen to use the fumigation incubation method because we find it reliable across a wide range of soils and well suited for studies with tracers. In addition, the measurements of $\mathrm{C}$ and $\mathrm{N}$ mineralization in the unfumigated control can be used to derive activity ratios such as the respiratory quotient (Anderson and Domsch 1993).

Calculation of biomass $\mathrm{N}\left(\mathrm{B}_{\mathrm{N}}\right)$ from the fumigation flush, which is the difference between $\mathrm{N}$ mineralized in the fumigated soil $\left(\mathrm{N}_{\mathrm{F}}\right)$ and that mineralized by an unfumigated control $\left(\mathrm{N}_{\mathrm{C}}\right)$, requires a factor $k_{\mathrm{N}}$ which is the proportion of biomass $\mathrm{N}$ mineralized. The calculation requires the assumption that non-microbial $\mathrm{N}$ mineralized in the fumigated sample $\left(\mathrm{N}_{\mathrm{F}}\right)$ is equal to, or a constant fraction of, that in the unfumigated control $\left(\mathrm{N}_{\mathrm{C}}\right)$. 


$$
B_{N}=\frac{N_{F}-N_{C}}{k_{N}}
$$

Values for $k_{\mathrm{N}}$ have been estimated by adding cultured organisms of known $\mathrm{C}$ and $\mathrm{N}$ content to soil prior to fumigation (Jenkinson 1976; Adams and Laughlin 1981; Marumoto et al. 1982; Voroney 1983; Nicolardot et al. 1986) or by in situ labeling of the microbial biomass with ${ }^{15} \mathrm{~N}$ (Voroney and Paul 1984). These studies have yielded values for $k_{\mathrm{N}}$ ranging from 0.22 to 0.68 .

The change in mineral $\mathrm{N}$ following fumigation and incubation $\left(\mathrm{N}_{\mathrm{F}}\right)$ is the net result of mineralization and immobilization occurring during the incubation (McGill et al. 1975). It, and thus $k_{\mathrm{N}}$, depend on the $\mathrm{C}$ and $\mathrm{N}$ contents of pre- and post-fumigation biomass and on the growth yield of the post-fumigation biomass. Jenkinson (1988) considered that the $\mathrm{C}: \mathrm{N}$ ratio of the microbial biomass in soils with no recent additions of high $\mathrm{C}: \mathrm{N}$ ratio plant material was relatively constant. From data in the literature, after discarding acid soils and some others, he obtained a ratio of 5.3 for $\left(\mathrm{C}_{\mathrm{F}}\right.$ $\left.-\mathrm{C}_{\mathrm{C}}\right) /\left(\mathrm{N}_{\mathrm{F}}-\mathrm{N}_{\mathrm{C}}\right)$ and calculated a $k_{\mathrm{N}}$ as 0.57 ; this corresponds to a biomass $\mathrm{C}: \mathrm{N}$ ratio of 6.7 . Jenkinson suggested that the chloroform fumigation incubation (CFI) method should not be used for soils with higher $\left(\mathrm{C}_{\mathrm{F}}-\mathrm{C}_{\mathrm{C}}\right) /\left(\mathrm{N}_{\mathrm{F}}-\mathrm{N}_{\mathrm{C}}\right)$ ratios than 7.5. However, unamended soils often exhibit $\left(\mathrm{C}_{\mathrm{F}}\right.$ $\left.-\mathrm{C}_{\mathrm{C}}\right) /\left(\mathrm{N}_{\mathrm{F}}-\mathrm{N}_{\mathrm{C}}\right)$ ratios greater than the limit suggested by Jenkinson (1988) and we have frequently observed net $\mathrm{N}$ immobilization after fumigation.

Jenkinson (1976) and Voroney (1983) showed that when organisms added to soil had a $\mathrm{C}: \mathrm{N}$ ratio of about 10 no net mineralization of biomass $\mathrm{N}$ was observed during the $10-\mathrm{d}$ incubation following fumigation. Addition of fungal biomass with $\mathrm{C}: \mathrm{N}$ ratios greater than 10 led to net immobilization of soil N. Voroney and Paul (1984) argued that the extent of immobilization was dependent on the regrowth after fumigation and that carbon mineralization $\mathrm{C}_{\mathrm{F}}$, without subtracting a control, was an indicator of the amount of regrown biomass. They developed a method for varying the value of $k_{\mathrm{N}}$ depending on the ratio of $\mathrm{C}$ and $\mathrm{N}$ mineralization $\left(\mathrm{C}_{\mathrm{F}} / \mathrm{N}_{\mathrm{F}}\right)$ using the relation:

$$
k_{N}=-0.014\left(C_{F} / N_{F}\right)+0.39
$$

The concept of adjusting $k_{\mathrm{N}}$ according to the $\mathrm{C}_{\mathrm{F}} / \mathrm{N}_{\mathrm{F}}$ ratio is useful because it allows $k_{\mathrm{N}}$ to vary with the original C:N ratio of the biomass while a fixed $k_{\mathrm{N}}$ presupposes a constant biomass $\mathrm{C}: \mathrm{N}$ ratio. However, problems arise in the calculation of $k_{\mathrm{N}}$ using the above Eq. 2. The function is discontinuous at $\mathrm{N}_{\mathrm{F}}=0$ and has large positive or negative values when $\mathrm{N}_{\mathrm{F}}$ is close to zero, it thus predicts improbably high or negative biomass $\mathrm{N}$ when $\mathrm{N}_{\mathrm{F}}$ is small or negative.

We re-examined the method for calculating microbial biomass $\mathrm{N}$ using a mathematical model of the decomposition and regrowth of the biomass after fumigation. The parameters of this model, the proportion of $\mathrm{C}$ mineralized during regrowth of the biomass after fumigation and its $\mathrm{C}: \mathrm{N}$ ratio, were estimated from data on $\mathrm{C}$ and $\mathrm{N}$ mineralization following addition of cultured organisms of known $\mathrm{C}$ and $\mathrm{N}$ content to fumigated soil.

\section{METHOD}

We based the calculation of biomass on the concept that the ratio of $\mathrm{N}_{\mathrm{F}} / \mathrm{C}_{\mathrm{F}}$ (the inverse of that used by Voroney and Paul) is a reflection of the $\mathrm{N}: \mathrm{C}$ ratio of the pre-fumigation biomass plus any non-microbial material that is metabolized, the $\mathrm{C}$ mineralization factor $(k)$ and the $\mathrm{C}: \mathrm{N}$ ratio of the post-fumigation biomass $(L)$. The calculation is based on the conceptual model of pre- and post-fumigation biomass shown in Fig 1 . When microbial biomass $\mathrm{C}\left(\mathrm{B}_{\mathrm{C}}\right)$ is made available for decomposition by fumigation, a fraction $(\alpha)$ is processed by the surviving, or re-inoculated, microbes and transformed either to $\mathrm{CO}_{2}\left(\mathrm{~B}_{\mathrm{C}} \alpha k\right)$ or to new biomass $\left(\mathrm{B}_{\mathrm{C}}\right.$ $\alpha(1-k))$ with a $\mathrm{C}: \mathrm{N}$ ratio $(L)$. In addition, a fraction $(p)$ of the non-microbial soil organic $\mathrm{C}$ metabolized by the unfumigated soil organisms $\left(\mathrm{C}_{\mathrm{C}}\right)$ is mineralized $\left(\mathrm{C}_{\mathrm{C}} p k\right)$ or incorporated into new biomass $\left(\mathrm{C}_{\mathrm{C}} p(1-k)\right)$. Some fraction $\beta$ of the microbial biomass $\mathrm{N}\left(\mathrm{B}_{\mathrm{N}}\right)$ is metabolized and either mineralized or incorporated into new biomass. A fraction $(q)$ of the $\mathrm{N}$ mineralized or immobilized in the unfumigated soil $\left(\mathrm{N}_{\mathrm{C}}\right)$ is also mineralized or immobilized.

We treated the addition of microbial biomass to fumigated soil as a special case of this model where there is no contribution of $\mathrm{C}$ from non-microbial sources. In this case the net $\mathrm{N}$ mineralization $\left(\mathrm{N}_{\mathrm{F}}\right)$ resulting from the addition of microbial biomass is equal to the difference in $\mathrm{N}$ contents of the decomposed fraction of the added organisms $B_{N} \beta$, and the newly grown post-fumigation biomass, $B_{C} \alpha(1-k) \frac{1}{\mathrm{~L}}$.

Therefore:

$$
N_{F}=B_{N} \beta-\left(B_{C} \alpha(1-k) \frac{1}{L}\right)
$$

$\mathrm{C}$ mineralized $\left(\mathrm{C}_{\mathrm{F}}\right)$ is equal to the product of the $\mathrm{C}$ content of the decomposed pre-fumigation biomass $\left(B_{C} \alpha\right)$ and the mineralization factor $k$,

$$
C_{F}=B_{C} \alpha k
$$

The ratio $\mathrm{N}_{\mathrm{F}} / \mathrm{C}_{\mathrm{F}}$ is determined by:

$$
\frac{N_{F}}{C_{F}}=\frac{B_{N} \beta}{B_{C} \alpha k}-\frac{(1-k)}{L k}
$$

By rearrangement of Eq. 5, biomass N/C can be expressed as:

$$
\frac{B_{N}}{B_{C}}=\frac{N_{F}}{C_{F}} \frac{\beta}{\alpha} k+\frac{(1-k) \alpha}{L \beta}
$$

let $k_{1}=\frac{\beta}{\alpha} k$ and $k_{2}=\frac{(1-k) \alpha}{L \beta}$

The parameter $k_{1}$ includes terms describing the fractions of the added biomass $C$ and $N(\alpha, \beta)$ metabolized by the postfumigation biomass and the fraction of the metabolized $\mathrm{C}$ which is mineralized $(k)$. The parameter $k_{2}$ combines terms for the fraction of added biomass $\mathrm{C} \alpha(1-k)$ which is incorporated into new biomass and the $\mathrm{C}: \mathrm{N}$ ratio of this biomass $(L)$ and the proportion of biomass $\mathrm{N}$ decomposed $(\beta)$. 


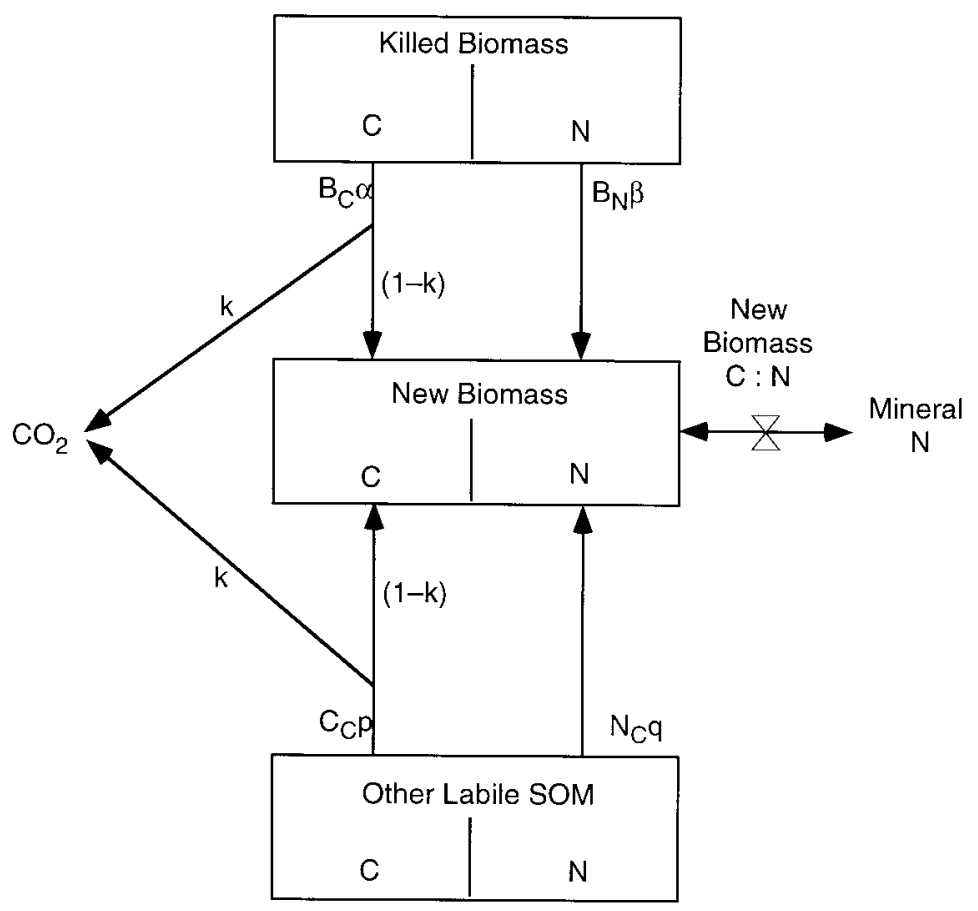

Fig. 1. The transformations of microbial biomass $\mathrm{C}$ and $\mathrm{N}$ following chloroform fumigation and incubation. $\mathrm{B}_{\mathrm{C}}=$ biomass $\mathrm{C}, \mathrm{B}_{\mathrm{N}}=$ biomass $\mathrm{N}, \mathrm{C}_{\mathrm{C}}=\mathrm{C}$ mineralized in 10-d incubation by unfumigated soil, $\mathrm{N}_{\mathrm{C}}=$ net $\mathrm{N}$ mineralization in unfumigated soil in 10 - $\mathrm{d}$ incubation, $\alpha=$ fraction of chloroform-killed biomass $\mathrm{C}$ decomposed in 10-d incubation, $\beta=$ fraction of chloroform-killed biomass $\mathrm{N}$ decomposed in 10-d incubation, $k=$ fraction of decomposed $\mathrm{C}$ mineralized, $p=$ residual fraction of $\mathrm{C}_{\mathrm{C}}$ in fumigated soil, $q=$ residual fraction of $\mathrm{N}_{\mathrm{C}}$ in fumigated soil.

Substituting in Eq. 6

$$
\frac{B_{N}}{B_{C}}=\frac{N_{F}}{C_{F}} k_{1}+k_{2}
$$

Equation 7 defines a linear relationship between the biomass $\mathrm{N}$ : $\mathrm{C}$ ratio $\left(\mathrm{B}_{\mathrm{N}} / \mathrm{B}_{\mathrm{C}}\right)$ and the ratio of post-fumigation mineralization $\mathrm{N}_{\mathrm{F}}: \mathrm{C}_{\mathrm{F}}$. We estimated the parameters $k_{1}$ and $k_{2}$ by regression using the measurements of $\mathrm{N}$ and $\mathrm{C}$ mineralization made after adding cultured bacteria and fungi at various $\mathrm{C}: \mathrm{N}$ ratios to soil (Table 1). These were used in the original Voroney and Paul (1984) calculation and were reported by Voroney (1983). We tested the parameters obtained from the Voroney data against the data of Jenkinson (1976) who also measured C and N mineralization following fumigation of soil to which organisms of known $\mathrm{C}$ and $\mathrm{N}$ contents were added.

The relationship between mineralization and the $\mathrm{C}$ and $\mathrm{N}$ contents of added organisms developed above can be extended to apply also to the fumigation response in the CFI method. This requires estimation of the contributions of non-microbial $\mathrm{C}\left(p \mathrm{C}_{\mathrm{C}}\right)$ and $\mathrm{N}\left(q \mathrm{~N}_{\mathrm{C}}\right)$ to net mineralization and new biomass formation in the fumigated soil during the 10 day incubation.

The fumigation responses due to the soil biomass $\left(\mathrm{C}_{\mathrm{FBIO}}\right.$, $\mathrm{N}_{\mathrm{FBIO}}$ ) then become

$$
\begin{aligned}
& C_{F B 10}=C_{F}-p C_{C} \\
& N_{F B 10}=N_{F}-q N_{C}
\end{aligned}
$$

Table 1. Mineralization of added bacterial and fungal $\mathrm{C}$ and $\mathrm{N}$ in fumigated soil during $10 \mathrm{~d}$ incubation at $28^{\circ} \mathrm{C}$

\begin{tabular}{lccc}
\hline & \multicolumn{3}{c}{ Proportion of biomass mineralized } \\
\cline { 2 - 4 } & $\mathrm{C}: \mathrm{N}$ & ${ }^{\mathrm{z}} p \mathrm{C}_{\mathrm{F}}$ & $\mathrm{y}_{p \mathrm{~N}_{\mathrm{F}}}$ \\
\hline Arthrobacter globiformis & 3.7 & 0.61 & 0.59 \\
Pseudomonas aeruginosa & 4.3 & 0.51 & 0.64 \\
Arthrobacter oxidans & 4.5 & 0.56 & 0.52 \\
Micrococcus flavus & 5.1 & 0.48 & 0.49 \\
Chrysosporium pannorum & 5.4 & 0.34 & 0.33 \\
Fusarium roseum & 5.9 & 0.33 & 0.37 \\
Zygorrhinchus mölleri & 7.4 & 0.38 & 0.20 \\
Mortierella nana & 8.6 & 0.40 & 0.09 \\
Mucor silvaticus & 8.8 & 0.29 & 0.18 \\
Aspergillus fumigatus & 9.5 & 0.34 & 0.13 \\
Trichoderma viride & 10.0 & 0.36 & 0.05 \\
Penicillium frequentans & 10.9 & 0.34 & -0.09 \\
Paecilomyces carneus & 11.3 & 0.35 & -0.13 \\
Cladosporium cladosporidia & 14.2 & 0.36 & -0.35 \\
\hline P &
\end{tabular}

$\mathrm{z}_{\mathrm{pC}}=(\mathrm{C}$ mineralized by fumigated soil + added organisms $-\mathrm{C}$ mineralized by fumigated unamended soil) / microbial $\mathrm{C}$ added.

${ }^{\mathrm{y}} \mathrm{pN}_{\mathrm{F}}=\left(\mathrm{NH}_{4}{ }^{+}\right.$mineralized by fumigated soil + added organisms $-\mathrm{NH}_{4}{ }^{+}$ mineralized by fumigated unamended soil) / microbial $\mathrm{N}$ added.

Substituting in Eq. 7:

$$
\frac{B_{N}}{B_{C}}=\frac{N_{F}-q N_{C}}{C_{F}-p C_{C}} k_{1}+k_{2}
$$

Horwath et al. (1996) developed a method to estimate the contribution of non-microbial $\mathrm{C}$ to the $\mathrm{C}$ mineralized following fumigation by relating the results of CFI to microscopic biomass measurements. The method estimates the 


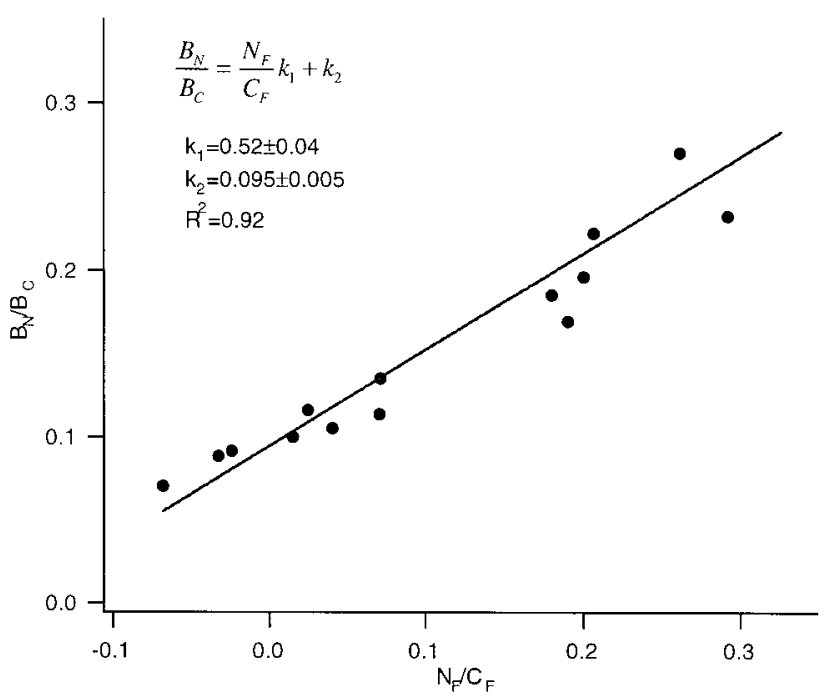

Fig. 2. The relationship between the $\mathrm{N}$ and $\mathrm{C}$ contents of cultured bacteria and fungi added to soil and the mineralization of $\mathrm{N}$ and $\mathrm{C}$ following chloroform fumigation and 10 day incubation (data of Voroney 1983).

proportion $(p)$ of $\mathrm{C}$ mineralization in the 10 day incubation of unfumigated soil $\left(\mathrm{C}_{\mathrm{C}}\right)$ which also occurs in the fumigated soil $\left(\mathrm{C}_{\mathrm{F}}\right)$.

$$
p=0.29 \frac{C_{F}}{C_{C}}+0.23
$$

We have no equivalent estimate of the contribution in the fumigated soil of $\mathrm{N}$ mineralized due to decomposition of materials other than the killed biomass $\left(q \mathrm{~N}_{\mathrm{C}}\right)$. Since we have no estimate of $(q)$ in Eq. 10, two simplifying assumptions were compared. The first assumption is that the mineralization ratio $\left(q \mathrm{~N}_{\mathrm{C}}: p \mathrm{C}_{\mathrm{C}}\right)$ of the non-biomass material that is decomposed in the fumigated soil is the same as that of the decomposed fraction of the killed biomass $\left(\mathrm{N}_{\mathrm{F}}: \mathrm{C}_{\mathrm{F}}\right)$. In this case, because the non-microbial components in the postfumigation incubation have no influence on the $\mathrm{N}_{\mathrm{F}} / \mathrm{C}_{\mathrm{F}}$ ratio; Eq. 10 reduces to Eq. 7.

$$
\text { if } \frac{N_{F}}{C_{F}}=\frac{q N_{C}}{p C_{C}} \text { then } \frac{N_{F}-q N_{C}}{C_{F}-p C_{C}}=\frac{N_{F}}{C_{F}}
$$

rearranging Eq. 7

$$
B_{N}=B_{C}\left(\frac{N_{F}}{C_{F}} k_{1}+k_{2}\right)
$$

An alternative simplifying assumption is that the fractions of $\mathrm{N}$ and $\mathrm{C}$ mineralization due to decomposition of non-biomass material in the fumigated soil are equal $(q=p)$. This would be true if the non-biomass material decomposed in the fumigated soil were qualitatively similar to that decomposed in the unfumigated soil. With this assumption $\mathrm{p}$ and $\mathrm{q}$ can be estimated by the method of Horwath et al. (1996) and Eq. 10 can be used to estimate biomass $\mathrm{N}$ from $\mathrm{C}$ and $\mathrm{N}$ mineralization measurements in fumigated and unfumigated samples after a 10-d incubation.

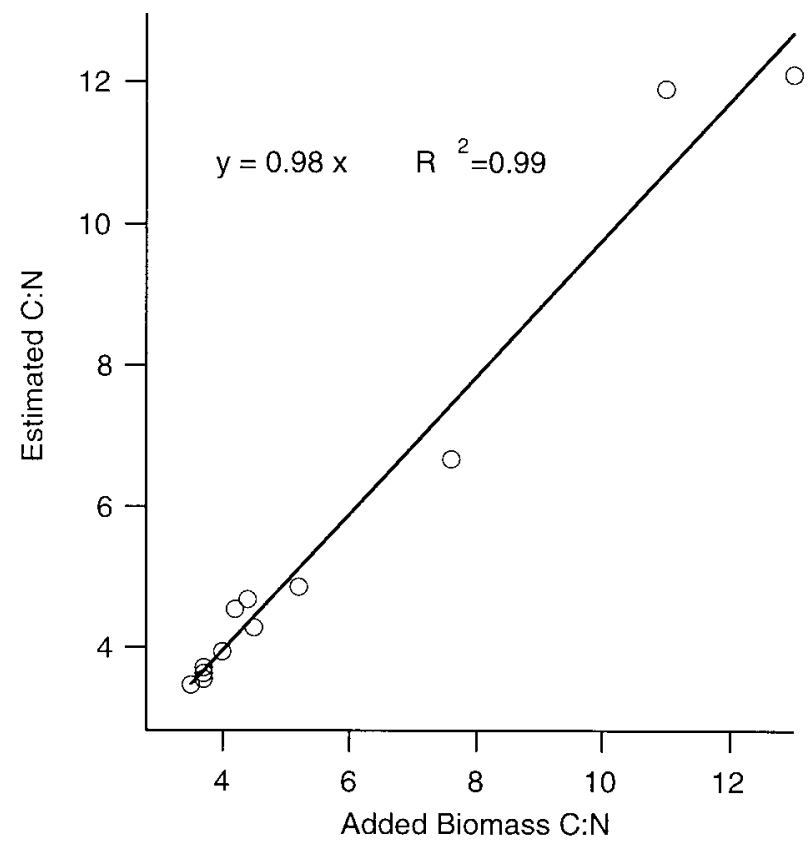

Fig. 3. The relationship between measured $\mathrm{C}: \mathrm{N}$ ratios of organisms added to fumigated soil (data of Jenkinson 1976) and C:N ratios predicted by

$$
\frac{B_{N}}{B_{C}}=\frac{N_{F}}{C_{F}} k_{1}+k_{2}
$$

where $k_{1}$ and $k_{2}$ were derived from the model in Fig. 2.

The intercept of the regression is not significantly different from zero.

\section{RESULTS AND DISCUSSION}

The experimental addition of known amounts of microbial biomass to fumigated soil represents a special case of Eq. 10 where $p=q=0$ because $\mathrm{N}_{\mathrm{F}}$ contains no contribution from sources of $\mathrm{C}$ or $\mathrm{N}$ other than the added organisms. The best fit $\left(R^{2}=0.92\right)$ to the Voroney data was obtained when $k_{1}$ was $0.52 \pm 0.04$ and $k_{2}$ was $0.097 \pm 0.006$ (Fig. 2). The model with these parameters was tested by predicting the $\mathrm{C}: \mathrm{N}$ ratios of organisms added to fumigated soil in the experiment by Jenkinson (1976). The predicted C:N ratios closely matched the measured $\mathrm{C}: \mathrm{N}$ ratios of the added organisms $\left(y=0.98 x, R^{2}=0.99\right.$, Fig. 3 ). This agreement provides strong evidence to support the model for two diverse sets of added organisms with a range of $\mathrm{C}: \mathrm{N}$ ratios in two different soils. We combined the Voroney and Jenkinson data to derive the overall parameter estimates, $k_{1}$ $=0.56 \pm 0.02, k_{2}=0.095 \pm 0.005$. Using these values for $k_{1}$ and $k_{2}$, Eq. 12 becomes:

$$
\frac{B_{N}}{B_{C}}=0.56 \frac{N_{F}-q N_{C}}{C_{F}-p C_{C}}+0.095
$$

Biomass $\mathrm{N}$ can be calculated by multiplying the N/C ratio by biomass $\mathrm{C}$

$$
B_{N}=B_{C}\left(0.56 \frac{N_{F}-q N_{C}}{C_{F}-p C_{C}}+0.095\right)
$$




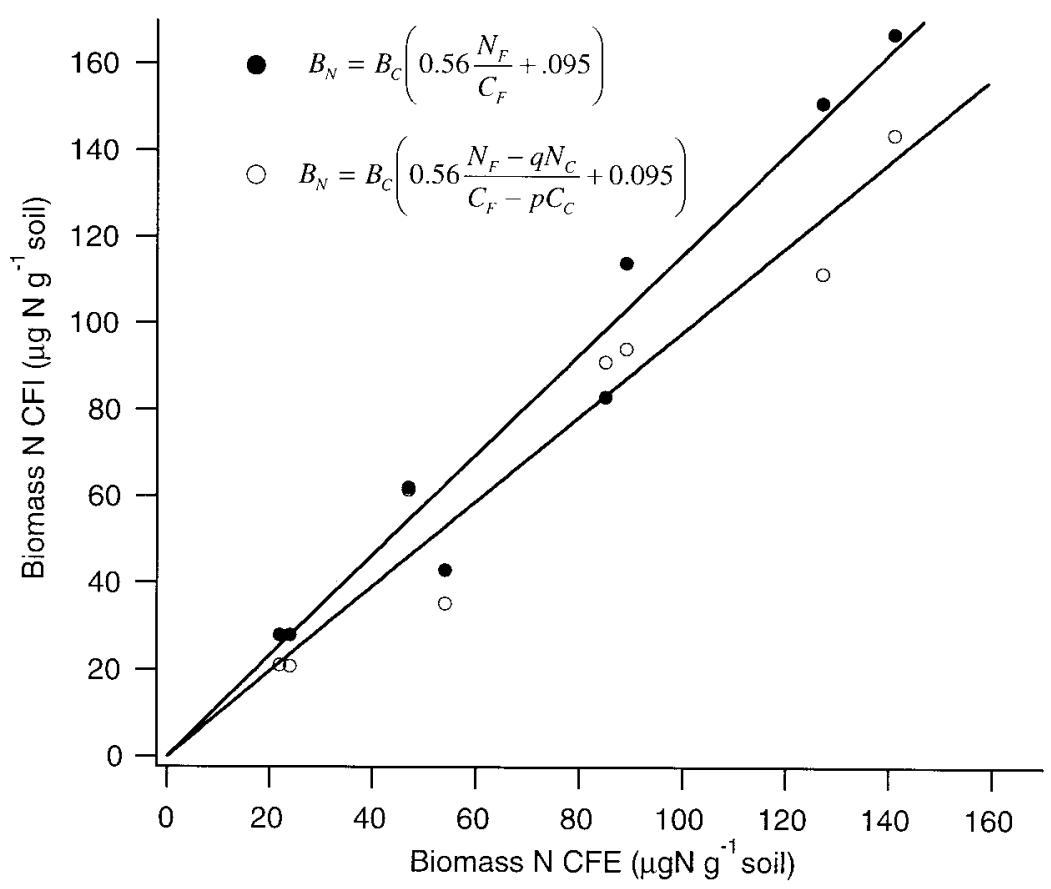

Fig. 4. Comparison of CFI biomass N, calculated with (•) and without (o) correction for residual mineralization of non-biomass constituents in the fumigated soil, with estimates obtained by CFE (data of Ocio and Brookes 1990). The intercepts of the regression lines are not significantly different from zero.

$$
\begin{aligned}
& \text { o } B_{N}=B_{C}\left(0.56 \frac{N_{F}-q N_{C}}{C_{F}-p C_{C}}+0.095\right) \text { where } p=q=0, y=(0.98 \pm 0.04) x, R^{2}=0.985 \\
& -B_{N}=B_{C}\left(0.56 \frac{N_{F}-q N_{C}}{C_{F}-p C_{C}}+0.095\right) \text { where } p=q=0.29\left(C_{F} / C_{C}\right)+0.23, y=(1.19 \pm 0.04) x, R^{2}=0.993 .
\end{aligned}
$$

We tested the concept and the parameter values by applying them to several data sets. Ocio and Brookes (1990) tested several methods for determining microbial biomass in soil following additions of straw. They concluded that biomass $\mathrm{C}$ and $\mathrm{N}$ in this amended soil could be determined by CFE but not by CFI. We recalculated the data of Ocio and Brookes using the CFI-C calculation described by Horwath et al. (1996) and biomass $\mathrm{N}$ by the calculation methods described here. CFI-biomass $\mathrm{N}$ calculated without correction for mineralization from non-biomass material, using Eq. $14(p=q=0)$, agreed closely with the values obtained by $\mathrm{CFE}\left(\mathrm{CFI} \mathrm{B} \mathrm{N}_{\mathrm{N}}=(0.98 \pm 0.04) \mathrm{CFE} \mathrm{B}_{\mathrm{N}}, R^{2}=0.985\right)$.

When a correction for the contribution of non-biomass material to mineralization in the fumigated soil was made [Eq. 14, $p=q=0.29 \times \mathrm{C}_{\mathrm{F}} / \mathrm{C}_{\mathrm{C}}+0.23$ (Horwath et al. 1996)] the relationship between $\mathrm{CFE}$ and $\mathrm{CFI}$ biomass $\mathrm{N}$ was again very strong but the CFI biomass $\mathrm{N}$ values were, on average, $19 \%$ higher than those obtained by CFE $\left(\mathrm{CFI} \mathrm{B} \mathrm{N}_{\mathrm{N}}=(1.19 \pm\right.$

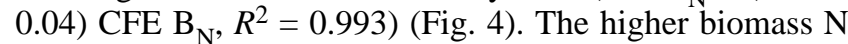
values obtained by the second method, where a "control correction" is made, are expected because the ratio of $\mathrm{C}$ to $\mathrm{N}$ mineralization in unfumigated soil is generally wider than that in fumigated soil (Ayanaba et al. 1976; Sparling and
Zhu 1993). This means that the errors arising from the contribution of $\mathrm{N}$ mineralized from non-biomass material $\left(\mathrm{N}_{\mathrm{C}} q\right)$ in the fumigated sample are small compared to those arising from $C$ mineralization $\left(C_{C} p\right)$ (Jenkinson 1988). The choice of an appropriate correction for $\mathrm{C}$ mineralization has remained controversial (Smith et al. 1996; Horwath et al. 1996; Wu et al. 1996) and has been an important factor favoring the widespread use of CFE. The method of partial "control" subtraction developed by Horwath et al. (1996) has been used here because it enables biomass $\mathrm{C}$ and $\mathrm{N}$ estimates to be made by CFI in soils for which the original Jenkinson method does not work.

Figure 5 shows CFI biomass $\mathrm{N}$ values for samples taken over a 6-yr period (1989-1995) from a long term ecological research (LTER) experiment (Robertson et al. 1997) at Kellogg Biological Station, Michigan. The soil, a sandy loam of $\mathrm{pH} 6.3$, containing $0.9-1.5 \%$ organic $\mathrm{C}$, had been cultivated in row crops for decades before it was converted in 1989 to 1 -ha plots with seven annual and perennial cropping systems. Both the Voroney and Paul (1984) and the Jenkinson (1988) calculations give improbable biomass $\mathrm{N}$ and $\mathrm{C}: \mathrm{N}$ ratios for many of the samples. This can be attributed to high $\mathrm{C}_{\mathrm{F}} / \mathrm{N}_{\mathrm{F}}$ ratios although the fundamental 

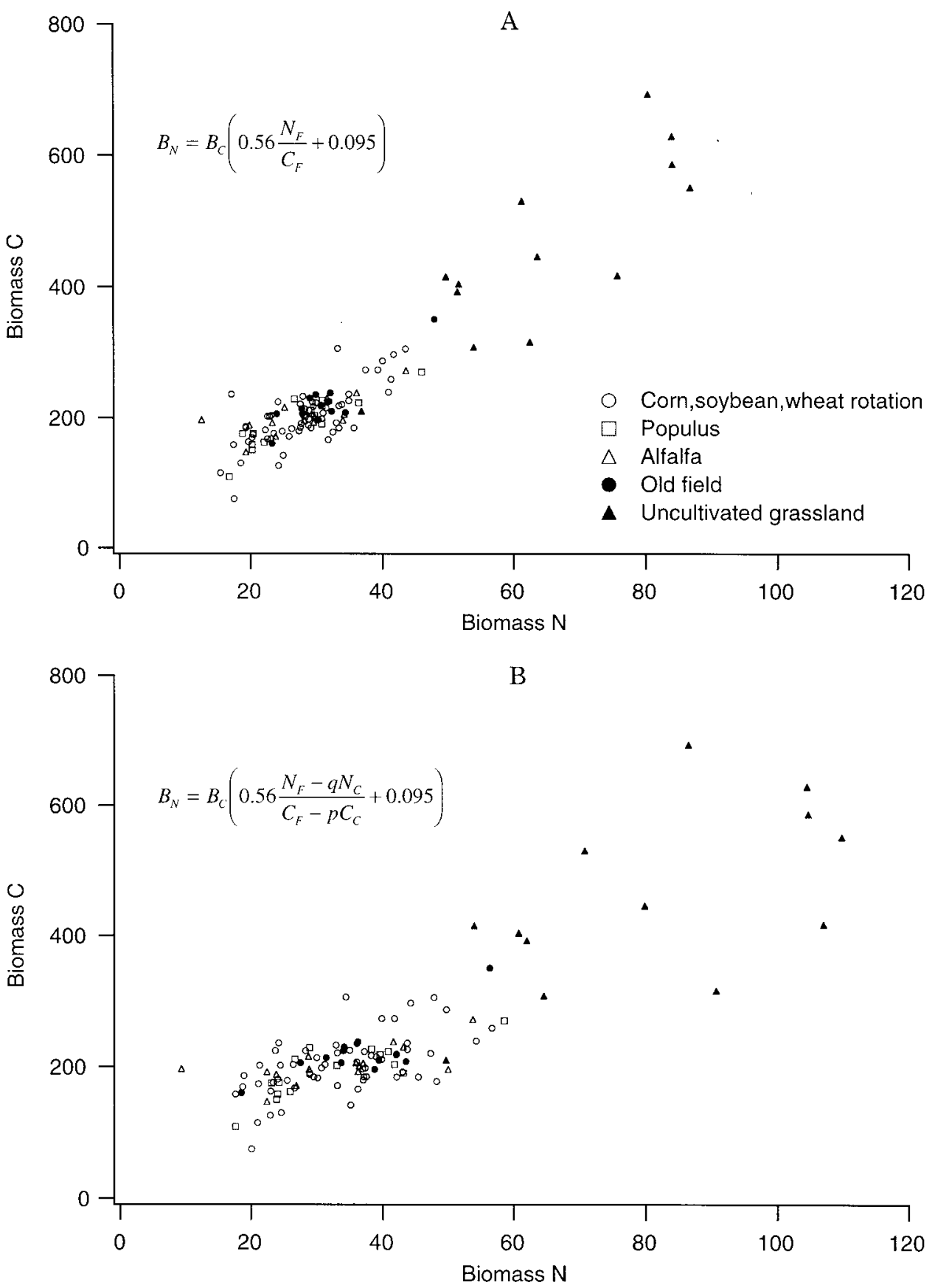

Fig. 5. Biomass $\mathrm{N}$ for annual, perennial agronomic and uncultivated grassland soils measured by CFI and calculated without (A) or with (B) correction for residual mineralization of non-biomass constituents in the fumigated soil.

(Mineralization data available at htpp:\\kbs.msu.edu/lter/data.)

reason for this is unclear. The new calculation method appears robust in all cases and estimates a mean biomass C:N ratio of 7.3 with a range of 4.3 to 15.8 when no control subtraction was made (Fig. 5a). When the mineralization was adjusted by partial subtraction of the control (Horwath et al. 1996) the mean C:N ratio was 6.4 with a range of 3.5 to 21.1. C:N ratios calculated using Jenkinson's (1988) method for biomass $\mathrm{N}$ had a mean of 7.9 and a range of 1.0 to 37.8 , after excluding 36 of the 117 samples for which extreme or negative $\mathrm{C}: \mathrm{N}$ ratios were obtained.

In soils where $\mathrm{C}_{\mathrm{F}} / \mathrm{N}_{\mathrm{F}}$ falls within the limits suggested by Jenkinson (1988), the estimates of biomass $\mathrm{N}: \mathrm{C}$ and $\mathrm{N}$ by the new method without control subtraction (Eq. 7) are similar to those obtained using the standard calculation and a $k_{\mathrm{N}}$ of 0.57 (Eq. 1). Values obtained with control subtraction (Eq. 13) are about 20\% higher (Fig. 6). However, the new 
A
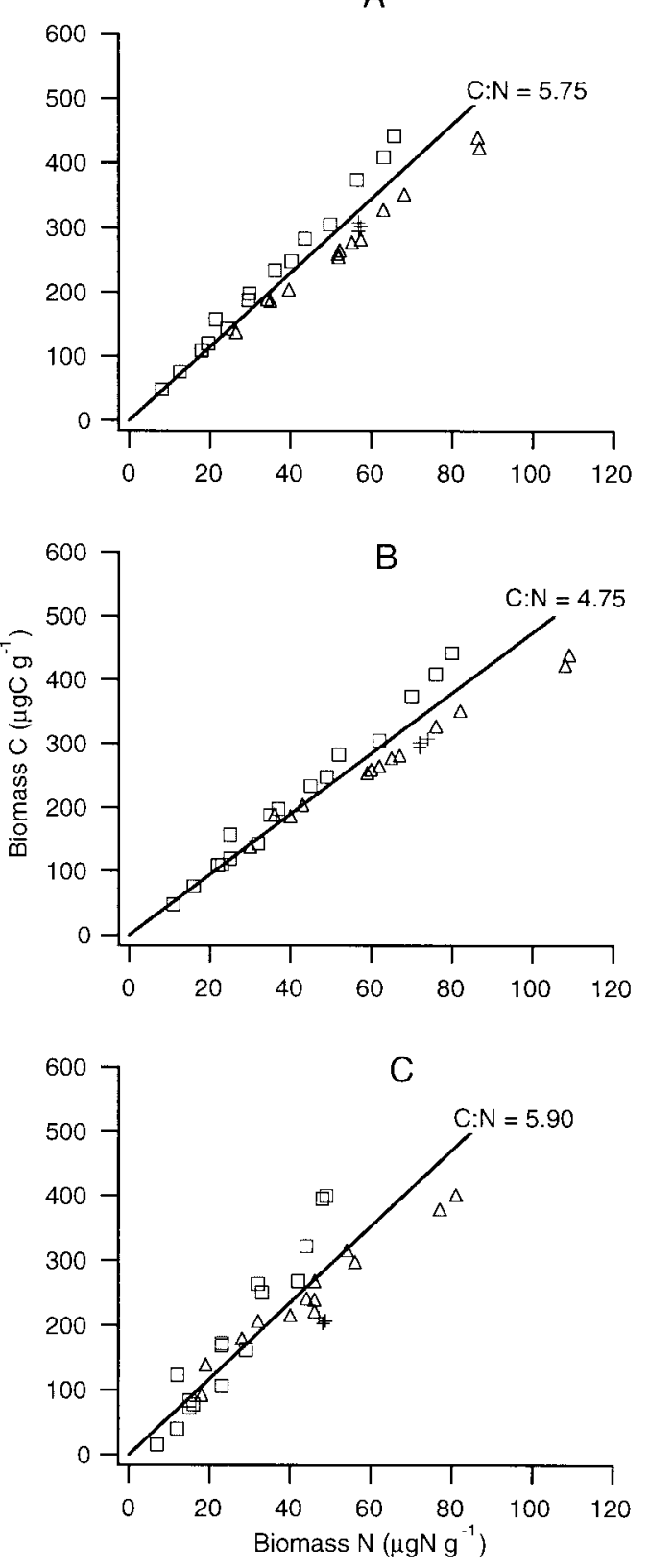

Figure 6. Biomass $\mathrm{C}: \mathrm{N}$ for soils in which the mineralization ratio $\left(\mathrm{C}_{\mathrm{F}}-\mathrm{C}_{\mathrm{C}}\right) /\left(\mathrm{N}_{\mathrm{F}}-\mathrm{N}_{\mathrm{C}}\right)$ is less than 7.5 ; calculated without (A) or with (B) correction for residual mineralization of non-biomass constituents in the fumigated soil and by the standard methods (C), (Jenkinson 1988). Data recalculated from Ayanaba et al. (1976) (D), Adams and Adams 1983 (ㅁ) and Shen et al. 1984 (+). $\mathrm{B}_{\mathrm{C}}$ for A and B calculated according to Horwath et al. (1996)

$B_{C}=2.44\left(C_{F}-p C_{C}\right)$ where $p=0.29 \frac{C_{F}}{C_{C}}+0.23$

(A) $\frac{B_{N}}{B_{C}}=0.56 \frac{N_{F}}{C_{F}}+0.095$

(B) $\frac{B_{N}}{B_{C}}=0.56 \frac{N_{F}-q N_{C}}{C_{F}-p C_{C}}+0.095$, and $q=p=0.29 \frac{C_{F}}{C_{C}}+0.23$

(C) $B_{N}=1.75\left(N_{F}-N_{C}\right), B_{C}=2.22\left(C_{F}-C_{C}\right), \frac{B_{N}}{B_{C}}=0.79 \frac{\left(N_{F}-N_{C}\right)}{\left(C_{F}-C_{C}\right)}$ calculation greatly extends the range of soils for which biomass $\mathrm{C}: \mathrm{N}$ and $\mathrm{N}$ can be determined by the CFI method and is robust even when fumigation is followed by net immobilization of $\mathrm{N}$.

\section{CONCLUSIONS}

The two methods described here for calculation of biomass $\mathrm{C}: \mathrm{N}$ and $\mathrm{N}$ from $\mathrm{CFI}$ data require five measurements; $10-\mathrm{d}$ $\mathrm{C}$ mineralization in fumigated and unfumigated soils $\left(\mathrm{C}_{\mathrm{F}}\right.$, $\mathrm{C}_{\mathrm{C}}$ ) and initial and 10-d mineral $\mathrm{N}$ contents in fumigated and unfumigated samples $\left(\mathrm{N}_{\mathrm{C}}=\right.$ mineral $\mathrm{N}$ after $10-\mathrm{d}$ incubation of unfumigated soil minus soil mineral $\mathrm{N}$ at day $0, \mathrm{~N}_{\mathrm{F}}=$ mineral $\mathrm{N}$ after $10-\mathrm{d}$ incubation of fumigated soil minus soil mineral $\mathrm{N}$ at day 0 ). Four of these measurements are required for biomass $\mathrm{C}$ and $\mathrm{N}$ determination by previous methods (Jenkinson 1976; Jenkinson 1988) for which measurement of initial mineral $\mathrm{N}$ is not required. Calculation of biomass $\mathrm{N}$ : $\mathrm{C}$ ratio $\left(\mathrm{B}_{\mathrm{N}} / \mathrm{B}_{\mathrm{C}}\right)$ can be made without correction for mineralization of non-biomass material in the fumigated sample:

$$
\frac{B_{N}}{B_{C}}=0.56 \frac{N_{F}}{C_{F}}+0.095
$$

This calculation uses only the measured $\mathrm{C}$ and $\mathrm{N}$ mineralization following fumigation and incubation and parameters determined from added organism experiments. Biomass $\mathrm{N}$ is then obtained by multiplying biomass $\mathrm{N}$ : $\mathrm{C}$ by biomass $\mathrm{C}$ which could be determined by any suitable method. The biomass $\mathrm{N}$ :C estimate can be refined by including terms defining the contribution of non-biomass materials to mineralization in the fumigated soil.

$$
\frac{B_{N}}{B_{C}}=0.56 \frac{N_{F}-q N_{C}}{C_{F}-p C_{C}}+0.095
$$

where $q \mathrm{~N}_{\mathrm{C}}$ and $p \mathrm{C}_{\mathrm{C}}=\mathrm{N}$ and $\mathrm{C}$ mineralization in the fumigated soil from sources other than chloroform-killed biomass, and:

$$
q=p=0.29 \frac{C_{F}}{C_{C}}+0.23
$$

This calculation includes measurements of $\mathrm{C}$ and $\mathrm{N}$ mineralization in the unfumigated soil and a fraction $p$, determined from calibration of CFI by microscopy (Horwath et al. 1996). On average, the calculation with partial control correction (Eq. 13) yields values $20 \%$ higher than the uncorrected version (Eq. 15). Values obtained from Eq. 13 may be more accurate than those from Eq. 15 because differences in the $\mathrm{C}: \mathrm{N}$ ratio of biomass and non-biomass materials decomposed in the fumigated soil are taken into account.

\section{ACKNOWLEDGMENTS}

This work was funded in part from the Kellogg Biological Station Long Term Ecological Research (LTER) project "Organisms in the Agricultural Landscape" (National Science Foundation grant DEB 92-22771 to Michigan State University). We thank two reviewers for very useful criticism of a previous manuscript of this paper. 
Adams, T. McM. and Adams S. N. 1983. The effects of liming and soil $\mathrm{pH}$ on carbon and nitrogen contained in the soil biomass. J. Agric. Sci. Camb. 101: 553-558

Adams, T. McM. and Laughlin, R. J. 1981. The effects of agronomy on the carbon and nitrogen contained in the soil biomass. J. Agric. Sci. (Camb.) 97: 319-327.

Anderson, T. H. and Domsch, K. H. 1993. The metabolic quotient for carbon dioxide as a specific activity parameter to assess the effects of environmental conditions, such as $\mathrm{pH}$, on the microbial biomass of forest soils. Soil Biol. Biochem. 25: 393-395.

Ayanaba, A., Tuckwell, S. B. and Jenkinson, D. S. 1976. The effects of clearing and cropping on the organic reserves and biomass of tropical forest soils. Soil Biol. Biochem. 8: 519-525.

Brookes, P. C., Landman, A., Pruden, G. and Jenkinson, D. S. 1985. Chloroform fumigation and the release of soil nitrogen: a rapid direct extraction method to measure microbial biomass nitrogen in soil. Soil Biol. Biochem. 17: 837-842.

Horwath, W. R., Paul, E. A., Harris, D., Norton, J., Jagger, L. and Horton, K. A. 1996. Defining a realistic control for the chloroform-fumigation incubation method using microscopic counting and 14C-substrates. Can. J. Soil Sci. 76: 459-467.

Jenkinson D. S. 1976. The effects of biocidal treatments on metabolism in soil. IV. The Decomposition of fumigated organisms in soil. Soil Biol. Biochem. 8: 203-208.

Jenkinson D. S. 1988. Determination of microbial biomass carbon and nitrogen in soil. Pages 388-386 in J. R. Wilson, ed. Advances in nitrogen cycling in agricultural ecosystems. Commonwealth Agricultural Bureau International, Wallingford, UK.

Jenkinson, D. S. and Powlson, D. S. 1976. The effects of biocidal treatments on metabolism in soil. V. A method of measuring soil biomass. Soil Biol. Biochem. 8: 209-213.

Marumoto, T., Anderson, J. P. E. and Domsch, K. H. 1982. Decomposition of ${ }^{14} \mathrm{C}$ - and ${ }^{15} \mathrm{~N}$-labeled microbial cells in soil. Soil Biol. Biochem. 14: 461-467.

McGill, W. B., Shields, J. A. and Paul, E.A. 1975. Relationship between carbon and nitrogen turnover in soil organic fractions of microbial origin. Soil Biol. Biochem. 7: 57-63.
Nicolardot, B., Guiraud, G. Chaussod, R. and Catroux, G. 1986. Mineralisation dans le sol de materiaux microbiens marques au carbone 14 et a l'azote 15: quantification de l'azote de la biomass microbienne. Soil Biol. Biochem. 18: 263-273.

Ocio, J. A. and Brookes, P. C. 1990. An evaluation of methods for measuring the microbial biomass in soils following recent additions of wheat straw and the characterization of the biomass that develops. Soil Biol. Biochem. 22: 685-694.

Robertson, G. P., Klingensmith, K. M., Klug. M. J., Paul, E. A., Crum, J. R. and Ellis, B. G. 1997. Soil resources, microbial activity and primary production across an agricultural ecosystem. Ecol. Appl. 7: 158-170.

Shen, S. M., Pruden, G. and Jenkinson, D. S. 1984. Mineralization and immobilization of nitrogen in fumigated soil and the measurement of microbial biomass nitrogen. Soil Biol. Biochem. 16: 437-444.

Smith, J. L., Halvorson, J. J. and Bolton, H. 1996. Determination and use of a corrected control factor in the chloroform fumigation method of estimating soil microbial biomass. Biol. Fertil. Soils 19: 287-291.

Sparling, G. and Zhu, C. 1993. Evaluation and calibration of biochemical methods to measure microbial biomass $\mathrm{C}$ and $\mathrm{N}$ in soils from Western Australia. Soil Biol. Biochem. 25: 1793-1801.

Voroney, R. P. 1983. Decomposition of crop residues. Ph.D. Thesis, University of Saskatchewan, Saskatoon, SK.

Voroney, R. P. and Paul, E. A. 1984. Determination of $k_{C}$ and $k_{N}$ in situ for calibration of the chloroform fumigation incubation method. Soil Biol. Biochem. 16: 9-16.

Wu, J. Brookes, P. C. and Jenkinson, D. S. 1996. Evidence for the use of a control in the fumigation-incubation method for measuring microbial biomass carbon in soil. Soil Biol. Biochem. 28: 511-518. 